\section{Japanese plan for doubling of public science spending}

Tokyo. Japan's public sector spending on science and technology will nearly double within four years if a resolution endorsed by a committee within the ruling coalition's strongest party, the Liberal Democratic Party (LDP), is adopted by the government. Implementation of the new resolution would fulfil a promise made in 1992 to double science spending by the turn of the century.

The resolution, agreed at a meeting of a recently formed LDP advisory committee on science and technology, calls for the national government to increase annual spending on science and technology to $¥ 4,660$ billion (US $\$ 43.7$ billion) by the end of the decade, 1.7 times current spending. Under the plan, research funds will double to $¥ 2,460$ billion, funds for personnel development and exchanges will quadruple to $¥ 120$ billion, and funds for basic infrastructure and maintenance treble to $¥ 585$ billion.

An LDP spokesman says a joint declaration formally adopting the resolution is expected from all the coalition's parties next month. The committee that passed this resolution has also been charged with advising the party's executive on framing the Basic Science and Technology Plan, formulation of which is required under a new science and technology law passed late last year (see Nature 378, 227; 1995).

Omi Koji, the LDP member responsible for drafting the law, is also playing a leading role in the new committee. $\mathrm{He}$ and other LDP politicians have managed to increase funding for science and technology despite the continuing recession and the government's commitment to cover the enormous losses of failed financial institutions.

During the drafting of the new plan for science, the committee heard from Susumu Tonegawa, joint winner of the 1987 Nobel prize for physiology or medicine. Tonegawa's testimony included stinging criticism of the university koza, or professorial chair system. The rigid hierarchical nature of this system stifles creativity in young researchers and is why Japan has obtained relatively few Nobel prizes, Tonegawa is reported to have said.

The resolutions for radical increases in funding have political support within the coalition, as well as the backing of ministries and agencies which will benefit from larger budgets. But Japan's Ministry of Finance, whose approval must be sought for all expenditure, is said to be resisting the new plans. Stephen Barker

\title{
US budget deal frees money
}

Washington. President Bill Clinton and the US Congress have finally agreed a firm budget for the 1996 financial year — which started last October - ending seven months of chaos and uncertainty at science funding agencies, as in other government departments.

In a deal finalized late last week which finally broke the budget impasse, the administration managed to eliminate several proposed relaxations of environmental law that Congress had sought to attach to the budget.

The two sides also reached a compromise on some of Clinton's favourite programmes. These included the Advanced Technology Program (ATP), which Congress Republicans have wanted to shut down. It will now receive \$221 million, compared with the $\$ 491$ million Clinton originally requested.

One surprise provision in the budget deal will prevent redundancies at the headquarters of the National Aeronautics and Space Administration announced only two weeks ago (see Nature 380, 657; 1996).

Another gives US corporations permission to export drugs and medical equipment that have been approved in specified developed countries - including Japan, Israel, South Africa and the European Union - but not in the United States.
In terms of overall funding for nonmilitary science and technology, the agreement will leave 1996 spending at about $\$ 32.6$ billion, 3 per cent less than the 1995 total of $\$ 34.2$ billion. This compares with a cut of 9 per cent in Congress's total nonmilitary budget - so science programmes have fared relatively well. When inflation is taken into account, science and technology spending has been cut by 6 per cent and all spending by 12 per cent.

The budget deal was particularly welcome at the National Science Foundation (NSF), one of several agencies that have been operating without an agreed budget for seven months. According to NSF officials, the agency is $\$ 75$ million better off than it would have been if - as was widely feared - no deal had been reached and it had remained dependent on temporary spending measures until the end of the financial year in September.

"I am immensely relieved and pleased that Congress has agreed upon a final budget," says Neal Lane, director of NSF. "We can now put behind us the distractions and confusion of the shutdowns and continuing resolutions," he adds, although he warns that the coming year "may prove to be even more difficult" (see below, left).

The \$221-million budget agreed for the

\section{Republicans outline 1997 priorities}

Washington. On the same day that Congress and the White House finally agreed budget terms for 1996, Republicans in the House of Representatives spelled out their science spending agenda for the 1997 financial year, which starts on 1 October.

The Republican plan includes sharp cuts to the National Aeronautics and Space Administration (NASA)'s Mission to Planet Earth, corresponding increases for other space science and significant reductions in climate change and energy supply research.

The new plan was endorsed on 24 April by the House Science Committee, chaired by Robert Walker (Republican, Pennsylvania), which has jurisdiction over most science programmes except for military and biomedical research.

The Omnibus Civilian Science Act proposed by the committee would cut spending on programmes under its jurisdiction from $\$ 20.3$ billion to $\$ 19.7$ billion. This contrasts sharply with proposals by the Clinton administration to increase such spending to $\$ 20.9$ billion

The act contains the same priorities as the committee put forward last year, although this time proposed cuts of $\$ 270$ million in Mission to Planet Earth would be ploughed back into other space science programmes (see box, above right).
The act again tries to eliminate the Advanced Technology Program in the Department of Commerce. But it does allow for a small increase in other programmes at the National Institute of Standards and Technology.

The committee proposes that the National Science Foundation (NSF) be give an increase of 1 per cent for research grants, but that it should be asked to cut administration costs. The NSF would also be told to close one of its seven directorates and following an amendment by Joe Barton (Republican, Texas) - to change its name to the National Science and Engineering Foundation.

George Brown (Democrat, California), the senior Democrat on the committee, branded the proposals "mean and extreme" and sought, without success, to substitute President Clinton's numbers in their place.

The act is unlikely to pass into law. But if last year's pattern is repeated, its numbers will be accepted by House appropriations committees, who will then have to compromise with the Senate and, finally, the administration. There is already speculation that this will be impossible before November's elections, and that the 1997 budget will have to wait for a new Congress and administration in the new year.

C. $M$. 


\section{for agencies}

ATP, funded through the Department of Commerce's National Institute of Standards and Technology (NIST) is much less than the president wanted. But it does keep the programme alive.

Existing projects will have first call on the money, says Michael Newman, a spokesman for NIST. But the agency hopes, in addition, to be able to launch a general competition for new grants this year.

Most of the final haggling over the 1996 budget concerned not money but the fate of so-called 'environmental riders' attached to budget bills by Congress in an attempt to relax environmental regulation without having to pass separate legislation.

Such riders, which would have curtailed the protection of wetlands by the Environmental Protection Agency, and extended the 'salvage foresting' of old trees, were removed altogether by Clinton.

Others, including the extension of a ban on the listing of new species under the Endangered Species Act, stay in the bill. But Clinton secured the rights for himself, as president, to waive them.

Nevertheless, some riders did take effect, including one that will stop the National Park Service from providing technical assistance to the International Convention on Biodiversity, and another enabling the University of Arizona to override environmental objections and proceed with construction of its proposed Large Binocular Telescope at Mount Graham, Arizona (see below). Colin Macilwain

\section{NASA head gets lean and mean}

Washington. The head of the US space agency told his congressional overseers last week that he does not want any more money for space science next year - even if Congress offers it. Reacting to a proposal from the House of Representatives Science Committee for an increase in funding for space science while cutting back on Earth science, Daniel Goldin, administrator of the National Aeronautics and Space Administration (NASA), spoke out forcefully against the plan in testimony before a House appropriations subcommittee the following day.

"I am not supportive of [additional funding for space science], regardless of what happens to Mission to Planet Earth," Goldin told the subcommittee, chaired by Jerry Lewis (Republican, California). He added that he was "vehemently opposed" to increasing money for space science in 1997, as he wants to continue teaching scientists a lesson about fiscal restraint.

Goldin said he wanted the "stress of the budget" to be felt by the space science community. Increasing the budget would send a message that scientists could return to the days of big, expensive missions and would put a chill on his philosophy of "better, cheaper, faster".

Republican staff members on the House Science Committee expressed surprise at Goldin's remarks. They said later that they did not intend to bring back large, expensive missions, but rather to fund the kinds of innovative technology and science programmes that Goldin has championed.

These include the Discovery planetary missions (which would receive $\$ 20$ million more than NASA requested), the New Millennium technology development programme (\$18.5 million more), Explorer projects ( $\$ 25$ million more) and missions to Mars ( $\$ 30$ million more).

Democratic opponents of the Republican plan say it is motivated less by a desire to boost space science than to eviscerate NASA's Mission to Planet Earth, particularly the Earth Observing System (EOS) of orbiting remote-sensing spacecraft. Robert Walker (Republican, Pennsylvania), chair of the Science Committee, has always contended that his opposition to EOS is not ideological, but based on his concern that the space agency can not afford the programme as at present conceived.

The committee's proposed 1997 budget would cut $\$ 374$ million from a $\$ 1.4$ billion request for the Mission to Planet Earth, and kill the Chem-1 mission altogether. The proposal also halves the $\$ 260$ million budget for the EOS data system. Goldin spoke angrily against the proposed cuts to EOS in his testimony, saying they would be "devastating to the programme".

Tony Reichhardt

\section{Mount Graham telescope gets green light from Washington}

Washington \& Munich. The long-delayed US-Italian project to build the large binocular telescope (LBT) on Mount Graham in Arizona might finally proceed, after President Bill Clinton signed a budget bill last week (see above, left) containing a provision specifically inserted to enable the project to overcome environmental objections.

A consortium of German astronomers is also poised to join the project, allowing it to be built to full specification. Officials of the University of Arizona (UoA) will this week ask a district court judge, Alfredo C. Marquez, to lift an injunction blocking construction of the telescope, in the light of the change in the law.

Construction came to a halt in 1994, after Marquez had ruled that a late site change placed the project in breach of the Endangered Species Act (see Nature 370, 407; 1994). Environmentalists have long tried to block the building of the LBT, first because of its alleged threat to a local species of red squirrel, and more recently on the grounds that the mountain is sacred to the San Carlos Apaches, a local Indian tribe.
Peter Strittmatter, director of the Steward Observatory at the university, declines to speculate how long it will be before construction work actually begins. Roger Angel, head of the mirror laboratory at UoA, which will build the mirrors for the telescope, says: "I hope we are talking days or weeks, but that is only speculation." Environmentalists intend to continue to fight the project, but have not announced their strategy.

There may be more surprises in store. Early this week, the Mount Graham forest was engulfed in a forest fire during the driest Arizona weather for many years. A spokeswoman for the Forest Service said that the threat to the observatory was "diminishing" as the wind direction changed.

Franco Paccini, director of the Osservatore Astrofisica in Florence, says that Congress's decision to put an end to the legal harassment of the construction plans is "great news". But he says that the LBT schedule has been so interrupted that a delay of a year might be expected.

Initially planned as a joint US-Italian venture, the project had not been able to secure the level of financing it had hoped for. Italy will contribute 25 per cent of the costs. The state of Arizona will pay 25 per cent, and other confirmed sources will increase the total US contribution to 42 per cent. The two countries had decided to go ahead with building the telescope with only a single mirror, hoping to find a partner to help complete the second mirror.

Driven by an enthusiastic astronomy community, Germany has now taken on that role. Scientists from various research institutions, chiefly the Max Planck Institute for Astronomy (MPIA) in Heidelberg and the Astronomy Institute Potsdam (AIP), have obtained promises of cash from various public sources.

According to Steve Beckwith, a director of the MPIA, there is now enough money committed to pay for the second mirror, and the partnership will suggest an initial level of participation of 15 per cent. But the German astronomy community would also like to provide instrumentation, and is aiming at a final contribution of 25 per cent.

Colin Macilwain \& Alison Abbott 